\title{
Factors Affecting Conservation Agriculture Technologies at Farm Lev- el in Bangladesh
}

\author{
M. A. Monayem Miah ${ }^{1^{*}}$ \\ M. Enamul Haque ${ }^{2}$ Richard W. Bell ${ }^{2}$ \\ Abdur Rashid ${ }^{1}$ \\ 1. Agricultural Economics Division, Bangladesh Agricultural Research Institute (BARI), Joydebpur, Gazipur \\ 2. Murdoch University, Australia \\ 3. Agricultural Economics Division, Bangladesh Rice Research Institute (BRRI), Joydebpur, Gazipur
}

M. A. Rouf Sarkar

M.

\begin{tabular}{|c|c|}
\hline ARTICLE INFO & ABSTRACT \\
\hline Article history & \multirow{12}{*}{$\begin{array}{l}\text { Conservation agriculture (CA) is a win-win approach that reduces op- } \\
\text { erational costs, including machinery, labour, and fuel, while increasing } \\
\text { yields, profit and better utilization of natural resources. Data and infor- } \\
\text { mation on farm level CA technology adoption are scarce in Bangladesh. } \\
\text { Therefore, the study was conducted at three Upazilas of Rajshahi and } \\
\text { Thakurgaon districts to assess adoption and farmers perceptions on CA } \\
\text { technology, and to determine the factors of CA technology adoption at } \\
\text { farm level in } 2017 \text {. A total of } 405 \text { farmers taking } 135 \text { adopters and } 270 \\
\text { non-adopters were selected randomly for this study. The study revealed } \\
\text { that CA technology adoption is still going on in the study areas. However, } \\
\text { the rates of adoptions of crop residue retention ( } 67 \%) \text { and crop rotations } \\
\text { (38.9\%) were much higher compared to minimum tillage (14.9\%). Resi- } \\
\text { due retention ( } 68.9 \% \text { and suitable crop rotations ( } 34.4 \%) \text { were also prac- } \\
\text { ticed by the non-adopters. The age, innovativeness, and extension contact } \\
\text { of the farmers and availability of VMP had significant positive influence } \\
\text { on the adoption of CA technologies. The major problems of adoption } \\
\text { were non-availability of minimum tillage planter, lack of knowledge } \\
\text { and awareness of the farmer, and no/little subsidy provision on planter. } \\
\text { Increasing the availability of VMP, providing training on CA methods, } \\
\text { and providing subsidy on planter are important to increase CA technology } \\
\text { adontion at farm level. }\end{array}$} \\
\hline Received: 1 December 2020 & \\
\hline Revised: 7 December 2020 & \\
\hline Accepted: 8 December 2020 & \\
\hline Published Online: 30 December 2020 & \\
\hline Keywords: & \\
\hline Conservation tillage & \\
\hline VMP & \\
\hline Residue retention & \\
\hline Crop rotations & \\
\hline Conservation agriculture & \\
\hline & \\
\hline
\end{tabular}

\section{Introduction}

A griculture in Bangladesh is well advanced in adopting farm mechanization particularly in land preparation, irrigation, and threshing. However, the growing threat to crop production is the shortage of labour which impacts especially on crop establishment, weed control, and harvesting ${ }^{[19]}$. In addition, prices of inputs such as labour, seed, fertilizer, pesticides, diesel, and irrigation water are also increasing that affects their optimum use, crop productivity and farm profitability ${ }^{[29]}$. Thus, Bangladesh agriculture is facing the challenge of increasing food security for its growing population and improving overall land use sustainability, while decreasing the need for labour, the costs of crop production and increasing farm profitability. Therefore, more foods have to produce from decreasing cultivable land through more efficient use of land and crop management technologies

*Corresponding Author:

M. A. Monayem Miah,

Agricultural Economics Division, Bangladesh Agricultural Research Institute (BARI), Joydebpur, Gazipur;

Email:monayem09@yahoo.com 
and through using natural resources that have minimal adverse impacts on soil and environment ${ }^{[1]}$. In this context, conservation agriculture (CA) and mechanization are becoming increasingly important to overcome the problems of declining agricultural productivity in Bangladesh.

CA is not an actual technology; rather, it refers to a wide array of specific technologies that are based on applying one or more of the three main principles (IIRR and ACT, 2005). The principles are (a) minimal soil disturbance; (b) crop residue retention; and (c) suitable crop rotations ${ }^{[41]}$. Soil tillage is one of the most important activities of agricultural land management which has significant impact on soil physical, chemical, and biological properties that affect crop yield ${ }^{[22]}$. Minimum tillage practice increases the levels of soil organic matter ${ }^{[6,15]}$, water retention capacity ${ }^{[4,25]}$, irrigation requirements ${ }^{[8,21]}$, increases crop yield and decreases production costs ${ }^{[32,12]}$, and minimized turn-around time between the crops ${ }^{[16]}$. Crop residue retention on the top of the soil with any number of tillage systems plays a crucial role in improving agronomic yield and environmental quality ${ }^{[1,31]}$. It significantly modifies various agronomic factors by increasing and stabilizing the soil moisture content, altering fertility and temperature in the topsoil layer, reducing soil erosion, nematode and sunlight incidence on the soil surface ${ }^{[33,39]}$. Long-term crop residue incorporation builds SOM level and $\mathrm{N}$ reserves, and increases the availability of macroand micro-nutrients ${ }^{[34]}$. Suitable crop rotation has many agronomic, economic and environmental benefits over continuous cropping ${ }^{[2]}$. Crop rotation can help maximize crop yield potential and profitability over time ${ }^{[26]}$, control weeds ${ }^{[7,20]}$, break disease cycles, limit insect and other pest infestations ${ }^{[37]}$, increase soil organic matter, and provide an alternative source of nitrogen ${ }^{[2,28]}$. Besides grain crops, the inclusion of legume in a cropping pattern can maintain soil fertility and sustain crop productivity to a great extent ${ }^{[9]}$.

Therefore, the productivity increase and sustainability of CA systems largely depend on tillage operations, systematic crop rotations, and in situ crop harvest residue management coupled with adequate crop nutrition. CA is a win-win approach that reduces operational costs, including machinery, labour, and fuel, while increasing yields and better utilization of natural resources ${ }^{[30]}$. It has the capacity to make more water available to the crops, and can mitigate, to some extent, the present climatic and socio-economic challenges faced by farmers ${ }^{[2]}$.

Realizing the importance of CA in Bangladesh, the scientists of Murdoch University, Australia with the support of Australian Government and in collaboration with Bangladesh Agricultural University, BARC, BARI, BRRI,
Department of Agriculture and Food of Western Australia, and NGOs has implemented the project "overcoming agronomic and mechanization constraints to development and adoption of conservation agriculture in diversified rice-based cropping in Bangladesh" funded by ACIAR since April 2012 to March 2017. The project has developed and accelerated the adoption of CA technology for selected soils, crops and cropping systems in different areas of Bangladesh, especially in the rainfed areas and those with supplementary irrigation. Respondent farmers have received benefits from cost saving crop production technologies and sustainable resource management through adopting CA technologies. They have established and grown different crops such as wheat, maize, pulses, oilseeds, jute, and rice successfully through CA technology ${ }^{[3,14]}$. Therefore, an attempt was made to assess the adoption of CA technology at farm level for providing feedback of the project to researchers and policy makers who can formulate appropriate policy guidelines to disseminate CA technologies to other new areas of the country.

\section{Specific Objectives}

(1) To assess the adoption status of CA technologies at farm level.

(2) To determine the factors influencing CA technology adoption at farm level.

(3) To assess the perceptions of farmers about CA technology adoption at farm level.

\section{Methodology}

\subsection{Study Area Selection}

CA technologies have been implemented or are being practiced in seven Upazilas in four districts of Bangladesh namely Rajbari, Thakurgaon, Rajshahi and Mymensingh. Considering project resources, logistic support and CA technology adoption, three Upazilas namely Durgapur and Godagari Upazilas of Rajshahi district and Sadar Upazila of Thakurgaon district were purposively selected for the study.

\subsection{Sampling Design and Data Collection}

The households were selected considering the level of adoption of CA technologies. At first, a complete list of farmers adopted CA technologies (i.e. minimal soil disturbance, crop residue retention, and suitable crop rotations) was prepared with the help of personnel from DAE and CA project. Then, a total of $135 \mathrm{CA}$ farmers taking 45 farmers from each Upazila were selected randomly for 
this study. Again, a total of 270 non-adopting farmers were randomly selected for this study as control. Thus, the total sample size was 405. Data and information were gathered from selected farmers using a pre-tested interview schedule. Data were collected during January-February, 2017.

\subsection{Analytical Techniques}

Collected data were edited, scrutinized, summarized and analyzed using computer software. Descriptive statistics were mostly used to present the results of the study. Moreover, the following Logit model was used to identify factors of CA technology adoption at farm level.

According to Gujarati ${ }^{[10]}$, the Logit model guarantees that the estimated probabilities lie in the $0-1$ range and that they are not linearly related to the explanatory variables. In addition, it is easier and more convenient to compute than the Probit model. Since the dependent variable is dichotomous, OLS cannot be used. MLE method was followed to run the Logit model using STATA software (Version 12). The specification of the model was as follows:

$$
\begin{gathered}
\operatorname{Logit}\{\mathrm{P}(\mathrm{Y}=1)\}=\log \{\mathrm{P} /(1-\mathrm{P})\}=\alpha+\beta_{1} \mathrm{X}_{1}+\beta_{2} \mathrm{X}_{2}+\ldots \ldots \ldots \\
+\beta_{\mathrm{K}} \mathrm{X}_{\mathrm{K}}
\end{gathered}
$$

Where, $\mathrm{Y}$ is a categorical response variable with $1=$ adopters and $0=$ otherwise; $\alpha$ is the intercept; $\beta_{1}, \beta_{2} \ldots . \beta_{k}$ are coefficients of independent variables $\mathrm{X}_{1} \mathrm{X}_{2} \ldots \mathrm{X}_{\mathrm{K}}$; $\mathrm{P}$ is the probability of adopting CA technology, and (1-P) is the probability that a farmer does not adopt CA technology.

The empirical Logit model was as follows:

$$
\begin{gathered}
\mathrm{Y}=\alpha+\beta_{1} \mathrm{X}_{1}+\beta_{2} \mathrm{X}_{2}+\beta_{3} \mathrm{X}_{3}+\beta_{4} \mathrm{X}_{4}+\beta_{5} \mathrm{X}_{5}+\beta_{6} \mathrm{X}_{6}+\beta_{7} \mathrm{X}_{7}+ \\
\beta_{8} \mathrm{X}_{8}
\end{gathered}
$$

Where, $\mathrm{Y}=$ Dependent variable $(1=$ Adopter, $0=$ Non-adopter), $\mathrm{X}_{1}=$ Farmer's age (year), $\mathrm{X}_{2}=$ Education (year of schooling), $\mathrm{X}_{3}=$ Family size (No./HH), $\mathrm{X}_{4}=\mathrm{Ln}$ Farm size (decimal), $\mathrm{X}_{5}=$ Availability of VMP (score), $\mathrm{X}_{6}$ $=$ Societal membership (wt. score), $\mathrm{X}_{7}=$ Innovativeness (wt. score), $\mathrm{X}_{8}=$ Extension contact (wt. score), $\alpha=$ Constant,

$\beta_{1} \beta_{2} \beta_{3} \beta_{4} \ldots \ldots \ldots \ldots \ldots \ldots . . . . . . \beta_{8}$ are the coefficients to be estimated.

\section{Results and Discussion}

\subsection{Status of CA Technologies Adoption}

Conservation agriculture is a new concept in Bangladesh although extensively practiced in many countries of the world. Farmers in Bangladesh generally practice one or two CA principles, but not three principles together. However, considerable efforts were made to popularize CA technology among interested farmers in different areas of Bangladesh. The adoption status of CA principles is discussed below.

Adoption of minimum tillage operations: In the study areas, Versatile Multi-crop Planter (VMP) is being promoted for crop establishment in minimum soil disturbance. Majority of the farmers belonged to adopter and non-adopter groups used full tillage operation by 2-WT (power tiller) for land preparation and $100 \%$ CA farmers used VMP for minimum soil disturbed crop establishment in single pass operation (Table 1). A study found that 41$43 \%$ less irrigation water was used by crops established by VMP planting as compared to a traditional tillage system ${ }^{[18]}$. The uses of Power Tiller Operated Seeder (PTOS) and country plough are rare in the study areas.

Table 1. Status of tillage/planting operations in the study areas

\begin{tabular}{ccccc}
\hline \multirow{2}{*}{$\begin{array}{c}\text { Tillage equipment/ } \\
\text { planter }\end{array}$} & \multicolumn{2}{c}{ Adopter $(\boldsymbol{n}=\mathbf{1 3 5})$} & \multicolumn{2}{c}{ Non-adopter $(\boldsymbol{n}=\mathbf{2 7 0})$} \\
\cline { 2 - 5 } 2-WT & $\mathbf{N}$ & $\mathbf{\%}$ & N & \% \\
\hline VMP & 115 & 85.2 & 270 & 100 \\
PTOS & 1 & 100 & -- & -- \\
Country plough & 1 & 0.7 & -- & -- \\
\hline
\end{tabular}

Respondent farmers were asked to give their opinion on intensive tillage in crop production. About $73 \%$ of the CA adopters and $26.3 \%$ non-adopters considered intensive tillage harmful for soil health and crop productivity. About $74 \%$ of the non-adopters considered intensive tillage beneficial to soil and crop yield (Table 2). Such response from non-adopters might be due to lack of knowledge and mindset on minimum soil disturbance. Both categories of farmers who responded in favor of minimum soil disturbing technologies mentioned various drawbacks of intensive tillage. Table 2 shows that more than $60 \%$ of the adopters and nearly $92 \%$ non-adopters gave the impression that soil fertility reduces due to intensive tillage. The emergence of enormous weeds in the crop field might be one of the causes of intensive tillage which was mentioned by $63.3 \%$ adopters and $11.3 \%$ non-adopters. Intensive tillage requires higher cost which was pointed out by $51 \%$ of the adopters and about $17 \%$ of non-adopters in the study areas. Loose soils are easily washed out during heavy rain or flood. Therefore, $47 \%$ of the adopters and $11.3 \%$ of non-adopters raised this issue due to intensive tillage. However, a good percentage $(29-46 \%)$ of the adopters also mentioned that intensive tillage requires higher dose 
of fertilizers and irrigation (Table 2).

Table 2. Farmers' perceptions on the intensive tillage of soil

\begin{tabular}{ccccc}
\hline \multirow{2}{*}{ Particular } & \multicolumn{2}{c}{ Adopter $(\boldsymbol{N = 1 3 5 )}$} & \multicolumn{2}{c}{ Non-adopter $(\mathbf{N = 2 7 0 )}$} \\
\cline { 2 - 5 } & $\mathbf{n}$ & $\mathbf{\%}$ & $\mathbf{n}$ & $\mathbf{\%}$ \\
\hline Response on intensive tillage & & & & \\
Harmful & 98 & 72.6 & 71 & 26.3 \\
$\begin{array}{c}\text { Beneficial } \\
\text { Disadvantages of intensive } \\
\text { tillage }\end{array}$ & 37 & 27.4 & 199 & 73.7 \\
Reduce of soil fertility & 59 & 60.2 & 65 & 91.5 \\
Emergence of enormous & 62 & 63.3 & 8 & 11.3 \\
$\quad$ weeds & 50 & 51.0 & 12 & 16.9 \\
Higher cost of tillage & 46 & 46.9 & 8 & 11.3 \\
$\quad$ Erosion of soil & 45 & 45.9 & 2 & 2.8 \\
Required higher fertilizer & 28 & 28.6 & 8 & 11.3 \\
Required higher irrigation & 4 & 4.1 & 5 & 7.0 \\
Loss of beneficial insects & 4 & & $\mathrm{n}=71$ & \\
Others* & 2 & 2.0 & 4 & 5.6 \\
\hline
\end{tabular}

Note: *Soil becomes hard, higher insects-diseases infestation, required higher seed, lower yield, etc.

Adoption status of crop residue retention: There are trade-offs in the role of residues in (1) boosting grain yields, (2) providing a resource for livestock feed and cooking, and (3) providing ground cover to reduce erosion potential ${ }^{[24]}$. The retention of crop residues can substantially reduce the amount of inorganic fertilizers use which brings both environmental and economic benefits to the farmers ${ }^{[38]}$. Knowingly or unknowingly the benefits of residue retention, many farmers in the study areas are retaining crop residues in their fields over the years. Both adopting and non-adopting farmers generally retain crop residues in the field after harvesting of rice (Boro \&Aman), wheat, and maize to a varied extent. Table 3 reveals that the average heights of crop residues kept by the CA farmers were 6.3", 6.2", 10.5" and 18.8" for Boro, Aman, wheat and maize, respectively. Although the average residue heights kept by the CA farmers for Boro and Aman rice were more or less equal to the heights kept by the non-CA farmers, the residue heights for wheat and maize were higher for non-CA farmers.

Table 3. Average height of crop residues retained in the field

\begin{tabular}{ccccc}
\hline Particular & Boro rice & Aman rice & Wheat & Maize \\
\hline A. Adopter & $n=98$ & $n=135$ & $n=135$ & $n=47$ \\
Minimum (inch) & 2 & 4 & 5 & 12 \\
Maximum (inch) & 12 & 10 & 18 & 24 \\
Mean (inch) & 6.3 & 6.2 & 10.5 & 18.8 \\
B. Non-adopter & $\mathrm{n}=$ & $n=270$ & $n=185$ & $n=76$ \\
Minimum (inch) & 213 & 2 & 6 & 12 \\
Maximum (inch) & 12 & 12 & 20 & 24 \\
Mean (inch) & 6.2 & 6.2 & 11.4 & 21.1 \\
\hline
\end{tabular}

Respondent farmers retained crop residues for many reasons. Improving the soil fertility was the prime reason for keeping a certain portion of crop residue stated by both CA $(95.6 \%)$ and non-CA farmers (97\%). Many farmers opined that when rice or wheat plants are slashed above the soil keeping some residues, the straw remains clean for animal feed. Therefore, a good percentage of both adopter and non-adopters in the study areas stated that they kept crop residue in order to remain straw clean for animal. About $12 \%$ CA farmers mentioned that the retention of crop residue ensures less fertilizers application which was might be due to increased fertility. A good percentage of both CA and non-CA farmers also stated some other reasons such as threshing of crops become easy (6.7-11.1\%), transporting harvests become easy (3.7$5.6 \%$ ), and reduction of soil \& nutrients erosion (Table 4).

Table 4. Reasons for retaining crop residues in the field

\begin{tabular}{|c|c|c|c|c|}
\hline \multirow{2}{*}{ Reasons for retaining crop residue } & \multicolumn{2}{|c|}{ Adopter $(n=135)$} & \multicolumn{2}{|c|}{ Non-adopter $(n=270)$} \\
\hline & Frequency & $\%$ & Frequency & $\%$ \\
\hline 1. Improve soil fertility & 129 & 95.6 & 262 & 97.0 \\
\hline 2. Straw remains clean/good feed & 20 & 14.8 & 59 & 21.9 \\
\hline 3. Crop harvest needs less labour & 19 & 14.1 & 44 & 16.3 \\
\hline $\begin{array}{l}\text { 4. Reduce the amount of fertilizer } \\
\text { uses }\end{array}$ & 16 & 11.9 & 2 & 0.7 \\
\hline 5. Threshing crops become easy & 9 & 6.7 & 30 & 11.1 \\
\hline $\begin{array}{l}\text { 6. Transporting harvests become } \\
\text { easy }\end{array}$ & 5 & 3.7 & 15 & 5.6 \\
\hline 7. Increases next crop's yield & 8 & 5.9 & -- & -- \\
\hline $\begin{array}{l}\text { 8. Reduces soil \& nutrients ero- } \\
\text { sion }\end{array}$ & 3 & 2.2 & 4 & 1.5 \\
\hline 9. Others* & 8 & 5.9 & 10 & 3.7 \\
\hline
\end{tabular}

Note: *Day labourer does not want to cut rice just up the soil, habitat of beneficial birds, climbing means for lentil crop, preserve soil moisture, straw dry early, and emergence of less weeds/grass.

Adoption status of crop rotations: A crop rotation is the practice of growing a series of different types of crops in the same area over a sequence of seasons. Continuously growing the same crop will tend to exploit the same soil root zone which can lead to a decrease in available nutrients for plant growth and to a decrease in root development ${ }^{[42]}$. Crop rotations can improve soil organic matter to a large extent and it has immense effect on soil physical and chemical properties and thereby on crop productivity ${ }^{[1]}$.

For many reasons, both CA and non-CA farmers in the study areas have been practicing crop rotations over the years, because they know well that monoculture reduces crop productivity. Some farmers practiced crop rotations for maintaining soil fertility. Table 5 shows that half of the CA farmers and $34.4 \%$ of the non-CA farmers adopted crop rotations over the years. Surprisingly, about $50 \%$ CA farmers did not practice crop rotations in the past. Currently, they are adopting suitable crop rotation since most CA farmers are passing $1^{\text {st }}$ year and $2^{\text {nd }}$ year through prac- 
ticing CA. However, they have intention to follow suitable crop rotations in future.

Table 5. Status of adoption of crop rotations in the study areas

\begin{tabular}{ccccc}
\hline \multirow{2}{*}{ Status of crop rotation } & \multicolumn{2}{c}{ Adopter $(\boldsymbol{n}=\mathbf{1 3 5})$} & \multicolumn{2}{c}{ Non-adopter $(\boldsymbol{n}=\mathbf{2 7 0})$} \\
\cline { 2 - 5 } & $\mathbf{N}$ & $\mathbf{\%}$ & $\mathbf{N}$ & $\mathbf{\%}$ \\
\hline Adopted & 68 & 50.4 & 93 & 34.4 \\
Not adopted & 67 & 49.6 & 177 & 65.6 \\
\hline
\end{tabular}

A wide range of cropping patterns has been practiced by the respondent farmers in the study areas. The major cropping patterns such as Lentil-Boro-T.Aman; Wheat-Jute-T. Aman; and Mustard-Boro-T.Aman were practiced by most of the CA and non-CA farmers (Tables $6 \&$ 7). The other important patterns were reported as Wheat-Maize-T.Aman; Wheat-Fallow-T.Aman and Wheat-Mungbean-T.Aman. The cultivation of pulse (lentil) is highly remunerative to the farmers. Therefore, many CA farmers started introducing pulse crops in the cropping patterns. Crop rotations with leguminous crops have the potential to increase soil nitrogen concentration through biological nitrogen fixation ${ }^{[9]}$. Some sampled farmers also thought that suitable crop rotations can reduce the incidence of insects and diseases.

Table 6. Crop rotations followed by CA adopter farmers in the study areas

\begin{tabular}{ccccccccc}
\hline \multicolumn{3}{c}{ Current year $(\boldsymbol{n}=\mathbf{6 8})$} & \multicolumn{3}{c}{ Previous year $(\boldsymbol{n}=\mathbf{6 8})$} & \multicolumn{3}{c}{ Two year before $(\boldsymbol{n}=\mathbf{6 8})$} \\
\hline $\mathbf{C P}^{*}$ & $\mathbf{n}$ & $\mathbf{\%}$ & $\mathbf{C P}^{*}$ & $\mathbf{n}$ & $\mathbf{\%}$ & $\mathbf{C P}^{*}$ & $\mathbf{n}$ & $\mathbf{\%}$ \\
\hline 1 & 16 & 23.5 & 4 & 15 & 22.1 & 4 & 18 & 26.5 \\
2 & 9 & 13.2 & 2 & 9 & 13.2 & 2 & 11 & 16.2 \\
3 & 8 & 11.8 & 1 & 6 & 8.8 & 1 & 6 & 8.8 \\
4 & 6 & 8.8 & 3 & 6 & 8.8 & 3 & 4 & 5.9 \\
5 & 5 & 7.4 & 6 & 4 & 5.9 & 5 & 3 & 4.4 \\
6 & 4 & 5.9 & 7 & 3 & 4.4 & 6 & 3 & 4.4 \\
Others & 20 & 29.4 & Others & 25 & 36.8 & Others & 23 & 33.8 \\
\hline
\end{tabular}

Notes: *Cropping pattern (CP): 1. Lentil-Boro-T.Aman; 2. WheatJute-T.Aman; 3. Wheat-Maize-T.Aman; 4. Mustard-Boro-T.Aman; 5. Wheat-Fallow-T.Aman; 6. Wheat-Mungbean-T.Aman; 7. Potato-Maize-T.Aman

Table 7. Crop rotations followed by non-adopter farmers in the study areas

\begin{tabular}{ccccccccc}
\hline \multicolumn{2}{c}{ Current year $(\boldsymbol{n = 9 3 )}$} & \multicolumn{3}{c}{ Previous year $(\boldsymbol{n}=\mathbf{9 3})$} & \multicolumn{3}{c}{$\begin{array}{c}\text { Two year before } \\
(\boldsymbol{n}=\mathbf{9 3})\end{array}$} \\
\hline CP* & $\mathbf{n}$ & $\mathbf{\%}$ & $\mathbf{C P *}$ & $\mathbf{n}$ & $\mathbf{\%}$ & $\mathbf{C P *}$ & $\mathbf{n}$ & $\mathbf{\%}$ \\
\hline 1 & 17 & 18.3 & 4 & 15 & 16.1 & 4 & 20 & 21.5 \\
2 & 17 & 18.3 & 1 & 9 & 9.7 & 1 & 11 & 11.8 \\
3 & 13 & 14.0 & 3 & 8 & 8.6 & 3 & 9 & 9.7 \\
4 & 8 & 8.6 & 8 & 8 & 8.6 & 2 & 8 & 8.6 \\
5 & 6 & 6.5 & 6 & 7 & 7.5 & 5 & 7 & 7.5 \\
6 & 6 & 6.5 & 2 & 6 & 6.5 & 8 & 5 & 5.4 \\
7 & 4 & 4.3 & 5 & 6 & 6.5 & 6 & 4 & 4.3 \\
Others & 21 & 22.6 & Others & 34 & 36.6 & Others & 29 & 31.2 \\
\hline
\end{tabular}

Notes: *Cropping pattern (CP): 1. Lentil-Boro-T.Aman; 2. Wheat-Fal-
low-T.Aman; 3. Wheat-Jute-T.Aman; 4. Mustard-Boro-T.Aman; 5. Wheat-Maize-T.Aman; 6. Lentil-Fallow-T.Aman; 7. Onion-Jute-T. Aman; 8. Fallow-Boro-T.Aman

Overall Rate of adoption of CA technologies: During the period (2012-2015) many farmers observed the benefits of CA technologies and adopted them gradually. This adoption process is still on-going in the study areas. However, the survey results showed that on an average $20.3 \%$ of farmers from Rajshahi and $10.1 \%$ of farmer from Thakurgaon districts adopted Versatile Multicrop Planter (VMP) for crop establishment in minimum disturbed soil (e.g., strip planting). Bed planting system can't be considered as CA system since it disturbed soils to a great extent ${ }^{[13]}$. In Rajshahi district, only $4.7 \%$ of the farmers used bed planter to prepare beds for cultivating crops, whereas $2.8 \%$ farmers established crops under zero tillage. A large portion (59.8-73.6\%) of the farmers from both areas retained crop residues in the crop fields. Again, about $39 \%$ of the farmers practiced crop rotations in the study areas (Table 8).

Table 8. Rate of adoption of conservation agriculture technologies

\begin{tabular}{|c|c|c|c|c|c|c|}
\hline \multirow[b]{2}{*}{ Particular } & \multicolumn{2}{|c|}{ Rajshahi } & \multicolumn{2}{|c|}{ Thakurgaon } & \multicolumn{2}{|c|}{ Both area } \\
\hline & n & $\begin{array}{c}\% \text { adop- } \\
\text { tion }\end{array}$ & $\mathbf{n}$ & $\begin{array}{c}\% \text { adop- } \\
\text { tion }\end{array}$ & n & $\begin{array}{l}\% \text { adop- } \\
\text { tion }\end{array}$ \\
\hline Total farm households & 316 & -- & 348 & -- & 664 & -- \\
\hline $\begin{array}{l}\text { Strip planting with } \\
\text { VMP users }\end{array}$ & 64 & 20.3 & 35 & 10.1 & 99 & 14.9 \\
\hline Bed planter users & 15 & 4.7 & -- & -- & 9 & 2.3 \\
\hline Zero tillage users & 9 & 2.8 & -- & -- & 9 & 1.4 \\
\hline $\begin{array}{c}\text { Crop residue retention } \\
\text { users }\end{array}$ & 189 & 59.8 & 256 & 73.6 & 445 & 67.0 \\
\hline $\begin{array}{l}\text { Crop rotation practic- } \\
\text { ing farmers }\end{array}$ & 112 & 35.4 & 146 & 42.0 & 258 & 38.9 \\
\hline
\end{tabular}

\subsection{Factors Influencing the Adoption of CA Tech- nologies}

The adoption of CA technologies was likely to be influenced by different socio-economic factors such as age, education, availability of VMP, extension contract, and innovativeness. The marginal effects of the variables determining adoption of CA technologies are presented in Table 9. Age of the farmer had significant influence on the adoption of CA technologies implying that the probability of adoption of the CA technologies decreases with the increase of farmers' age. It means that young farmers are the most adopters of CA technologies. Marginal coefficient indicates that if the age of farmer decreases by $100 \%$, the probability of adopting CA technologies would be increased by $0.45 \%$.

Usually, education has positive influence on new technology adoption ${ }^{[27,40]}$. In this study, education had significant negative impact on the adoption of CA technologies 
implying that the probability of adoption of CA technologies decreases with the increase of the year of schooling. It means that low educated farmers are the most adopters of CA technologies compared to higher educated farmers in the study areas. Marginal coefficient reveals that if the year of schooling decreases by $100 \%$, the probability of adopting CA technologies would be increased by $2.06 \%$.

Table 9. Marginal effect of the variables determining adoption of CA technologies among respondent farmers

\begin{tabular}{|c|c|c|c|c|}
\hline Explanatory variable & $D y / d x$ & SE & z-statistic & Probability \\
\hline Age (year) & $-0.0045^{* *}$ & 0.0021 & -2.19 & 0.028 \\
\hline $\begin{array}{c}\text { Education (year of school- } \\
\text { ing) }\end{array}$ & $-0.0206^{* * *}$ & 0.0071 & -2.87 & 0.004 \\
\hline Household size (No./HH) & 0.0178 & 0.0124 & 1.43 & 0.152 \\
\hline LnFarm size (decimal) & 0.0222 & 0.0366 & 0.60 & 0.545 \\
\hline $\begin{array}{c}\text { Availability of VMP (score) } \\
\text { (Scale, } 0-4 ; 0=\text { not available, } \\
4=\text { plenty) }\end{array}$ & $0.4341 * * *$ & 0.0478 & 8.94 & 0.000 \\
\hline $\begin{array}{l}\text { Societal membership (wt. } \\
\text { score) } \\
\text { (Scale, } 0-4 ; 0=\text { No member- } \\
\text { ship, } 4=\text { Executive member) }\end{array}$ & 0.0351 & 0.0249 & 1.42 & 0.156 \\
\hline $\begin{array}{l}\text { Innovativeness (wt. score) } \\
\text { (Scale, } 0-2 ; 0=\text { no involve- } \\
\text { ment, } 2=\text { involved) }\end{array}$ & $0.0311 * * *$ & 0.0115 & 2.69 & 0.007 \\
\hline $\begin{array}{l}\text { Extension contract (wt. } \\
\text { score) } \\
\text { (Scale, } 0-4 ; 0=\text { no contact, } \\
4=\text { regular contact) }\end{array}$ & $0.0240 * * *$ & 0.0072 & 3.29 & 0.001 \\
\hline
\end{tabular}

Note: Dependent variable $=\mathrm{CA}$ technology adoption $($ Adopter $=1$, Non-adopter $=0$ )

No. of observation $=403 ;$ LR chi-square $(8)=202.61 ;$ Log likelihood $=$ -154.27; Pseudo $R^{2}=0.3964$

'***'\& '**' represent significant at $1 \%$ and $5 \%$ level respectively

Higher score value represents the higher probability of CA technology adoption

Majority of the farmers in the study areas are unable to purchase a 2WT along with a VMP for crop establishment and practicing of CA. On the other hand, farmer's shallow knowledge on the advantage of minimum tillage and CA influences farmers not to adopt CA technology. In these circumstances, the availability of VMP in the locality is a crucial factor that highly influences farmers to adopt CA technology due to its demonstration effects and LSP's promotional activities. The marginal coefficient of VMP availability is positive and highly significant implying that the adoption probability of CA technologies would be increased by $43.41 \%$, if the availability of VMP is increased by $100 \%$.

The sampled farmers' contact with different extension personnel such as Agriculture Officer, Sub Assistant Agriculture Officer, BARI scientist and neighbouring farmers had a positive and highly significant relationship with the probability of adopting CA technologies. Logit estimate also shows that there is a positive and significant relationship between
CA technology adoption and extension contact. The probability of adopting CA technologies will be increased by $2.4 \%$, if the extension contact is increased by $100 \%$.

Progressive farmers always tend to adopt new technology. The marginal coefficient of innovativeness is positive and significant at $1 \%$ level. If the aforesaid variable is increased by $100 \%$, the probability of adoption of the CA technologies would be increased by $3.11 \%$ (Table 9 ).

\subsection{Perception of Farmers about CA Technology Adoption}

The CA adopting farmers in the study areas were asked to point out the advantages of CA technologies that were experienced over the last one or two years back. They mentioned many positive benefits of CA technology during crop production (Table 10). The highest proportion of CA farmers $(95.6 \%)$ mentioned that they could save labour costs in many operations of crop cultivation. More than 94\% farmers opined that CA systems significantly reduced the cost of land preparation and seed sowing since VMP requires single pass to complete planting and seeding operations. Another important observation of the farmers was that adoption of CA technology required less amounts of seed and seed placement was also better $(91.1 \%)$ compared to conventional cultivation. Many farmers (63.7$69.6 \%$ ) opined that CA technologies could successfully reduce the amount of irrigation water and fertilizer. The results of several studies ${ }^{[14,35-36]}$ also supported the statement of the farmers. Many CA farmers told that weeding and pesticides application (65.2\%) and crop harvest $(66.7 \%)$ are become easy due to line sowing of the seeds under strip tillage. The other positive observations of the farmers were increase in soil fertility $(63 \%)$, possibility of timely seed sowing (60\%), low attack of insects and diseases $(34.1 \%)$, and good yield with lower cost.

Table 10. Benefits of $\mathrm{CA}$ technology adoption as perceived by CA farmers

\begin{tabular}{ccc}
\hline Advantages & Frequency & \% response \\
\hline $\begin{array}{c}\text { 1. Require less labour and saving cost of } \\
\text { labour }\end{array}$ & 129 & 95.6 \\
$\begin{array}{c}\text { 2. Require less amount of seed/good } \\
\text { placement of seed }\end{array}$ & 127 & 94.1 \\
3. Require comparatively less irrigation & 94 & 69.6 \\
4. Require comparatively less fertilizer & 86 & 63.7 \\
5. Weeding and pesticides application & 88 & 65.2 \\
become easy & 90 & 66.7 \\
6. Crop harvests become easy & 85 & 63.0 \\
7. Increase soil fertility & 81 & 60.0 \\
8. Timely seed sowing possible & 46 & 34.1 \\
9. Incidence of low insects and diseases & 41 & 30.4 \\
10. Good yield with lower cost &
\end{tabular}


The respondent farmers also mentioned some negative sides of CA technologies. More than half of the CA farmers complained that CA machineries especially VMP was not available in the study areas. All types of fertilizers could not be applied together using VMP which was mentioned by $36.3 \%$ farmers. Skill operator is very important for operating VMP. But skill operators are scares in the study areas. About $34.1 \%$ farmers complained this as a problem. Generally, loam and sandy loam soils are suitable for strip planting with VMP. It can't be operated in the clay or other hard types of soils which was opined by $32.6 \%$ farmers. Weed management in CA is an important task. The emergence of huge weeds in the CA fields was a crucial problem encountered by about $9 \%$ of the CA farmers. The other problems faced by a small number of farmers were maintenance of crop rotation is a difficult task and minimum tillage produces less yields (Table 11). However, these statements were appeared might be due to lack of their mindset towards conservation agriculture.

Table 11. Disadvantages of CA technology adoption faced by CA farmers

\begin{tabular}{ccc}
\hline Disadvantages & Frequency & \% responses \\
\hline $\begin{array}{c}\text { 1. Non-availability of CA machineries } \\
\text { 2. All types of fertilizers can't be applied } \\
\text { together }\end{array}$ & 71 & 52.6 \\
$\begin{array}{c}\text { 3. VPM operation needs skill operators } \\
\text { 4. All soils are not suitable for CA practice }\end{array}$ & 46 & 36.3 \\
5. Emergence of more weeds & 12 & 34.1 \\
6. Maintenance of crop rotation is a diffi- & 3 & 32.6 \\
$\quad$ cult task & 2 & 2.2 \\
7. Minimum tillage produces less yield & & 1.5 \\
\hline
\end{tabular}

\subsection{Future Challenges for CA Adoption}

The adoption of such promising technologies is not linear and its adoption depends on many other factors like environmental, socioeconomic, institutional and political circumstances and constraints, rather than technology alone. Future challenges of CA adoption are furnished in Table 12.

The adoptions of CA technologies have to face different challenges in future. The first ranked challenge will be the lack of knowledge and awareness of the farmers about the benefits of CA technologies. On an average, about $93 \%$ respondent farmers mentioned this as one of the challenges of its adoption. The availability of CA machineries is the pre-requisite of successful CA adoption. But for different reasons CA machineries are not widely available in the study areas that will be the main barrier of its wider adoption. The level of farmers' education in the study areas is not up to the mark. Most of them are illiterate and low educated which is also a challenge for the successful adoption of CA technologies at farm level. Although less educated farmers are more adopters of CA technologies in the study areas. However, more than $80 \%$ respondent farmers raised this issue as a future challenge of its adoption. Most of the farmers in the study areas are poor and have no ability to purchase 2WT along with CA planter (VMP) for minimum tillage. They have to depend mainly on the local service providers of CA and others machineries for tillage and threshing operations. About 55\% farmers stated it as a future challenge for CA adoption. For expanding CA technologies at farm level, the Australian funded CA project provided price support (50 and $25 \%$ in year 1 and year 2, respectively) on CA machineries especially on the price of VMP among interested farmers. This price support provision has been taken out after the completion of the project. Such situation has been considered by $43 \%$ of the farmers as a challenge for $\mathrm{CA}$ adoption in future. Finally, the successful adoption of CA technologies also depends on many other organizations such as DAE, Bank, Research institutes, machineries manufacturers, etc. Strong collaborative backward and forward linkage program are essential for wider adoption of CA technologies in the study areas which will be also an important challenge toward CA adoption in Bangladesh.

Table 12. Future challenges of CA adoption in the study areas

\begin{tabular}{lccccccc}
\hline \multirow{2}{*}{ Challenges } & $\begin{array}{c}\text { Adopter } \\
(\boldsymbol{n}=\mathbf{1 3 5})\end{array}$ & $\begin{array}{c}\text { Non-adopter } \\
(\boldsymbol{n}=\mathbf{2 7 0})\end{array}$ & $\begin{array}{c}\text { All category } \\
(\boldsymbol{n}=\mathbf{4 0 5})\end{array}$ \\
\cline { 2 - 7 } & $\mathbf{n}$ & $\mathbf{\%}$ & $\mathbf{n}$ & $\mathbf{\%}$ & $\mathbf{n}$ & $\mathbf{\%}$ \\
\hline $\begin{array}{c}\text { 1. Lack of knowledge/awareness } \\
\text { toward CA }\end{array}$ & 124 & 91.9 & 252 & 93.3 & 376 & 92.8 \\
$\begin{array}{c}\text { 2. Non-availability of CA machin- } \\
\text { eries }\end{array}$ & 114 & 84.4 & 230 & 85.2 & 344 & 84.9 \\
$\begin{array}{c}\text { 3. Lack of farmers' education and } \\
\text { training }\end{array}$ & 117 & 86.7 & 210 & 77.8 & 327 & 80.7 \\
$\begin{array}{c}\text { 4. Farmers' non-ability to pur- } \\
\text { chase CA planter }\end{array}$ & 82 & 60.7 & 141 & 52.2 & 223 & 55.1 \\
$\begin{array}{c}\text { 5. No price subsidy on CA planter } \\
\begin{array}{c}\text { 6. Lack of cooperation from sup- } \\
\text { porting organizations }\end{array}\end{array}$ & 70 & 51.9 & 103 & 38.1 & 173 & 42.7 \\
\hline
\end{tabular}

\section{Conclusions and Recommendations}

\subsection{Conclusions}

CA is becoming important to many farmers to overcome the problems of labour shortage, increases of cultivation costs, declining agricultural productivity, and farm profitability. The process of CA technology adoption is still on-going in the study areas. Although the level of 
adoptions of crop residue retention and crop rotations are much higher, the adoption of minimum tillage is too small. Traditionally, a good segment of the non-CA farmers retain crop residues in the field and practice suitable crop rotations over the year. Various inherent qualities such as younger age, innovativeness, and extension contact of the farmers have significantly influenced them to adopt CA technologies. The availability of VMP is another crucial factor that influences farmers to adopt the technology (minimum tillage) to a great extent. Although CA technologies show potentials in many aspects, it faces some challenges towards its higher adoption. The lack of farmer's awareness and non-ability to purchase CA planter, non-availability of CA machineries, no subsidy or price support on CA planter, and lack of cooperation from supporting organizations are the major challenges of its higher adoption.

\subsection{Recommendations}

The following recommendations are crucial for increasing the adoption of these promising and versatile technologies to make agriculture sustainable and farm business profitable.

(1) The government should provide practical and field oriented training on CA technologies to the enthusiastic farmers. In this respect, the government should broadcast the positive impacts of CA technologies using suitable mass media.

(2) Demonstration and field day have greater impacts on technology adoption. Therefore, the government should demonstrate CA activities among farmers and conduct field days for wider adoption of CA technologies.

(3) The government should make minimum tillage planters available to the farmers through providing soft loan to the manufacturers and interested farmers. Subsidized price can also play important role in spreading out minimum tillage planters among farmers.

(4) Extension personnel involved in technology dissemination generally do not come to the farmer after the completion of the project. Therefore, the government should give emphasis on developing effective monitoring mechanism for CA technology disseminators.

(5) The government should make good cooperation among different organizations such as DAE, Bank, Research institutes, machineries manufacturers etc. for higher adoption of CA technologies in Bangladesh.

\section{References}

[1] Alam M. K., N. Salahin, S. Islam, R. A. Begum, M. Hasanuzzaman, M. S. Islam, M. M. Rahman. Pat- terns of change in soil organic matter, physical properties and crop productivity under tillage practices and cropping systems in Bangladesh[J]. Journal of Agricultural Science, 2016a: 1-23.

[2] Alam M. K., W. K. Biswas, R. W. Bell. Greenhouse gas implications of novel and conventional rice production technologies in the Eastern-Gangetic plains[J]. Journal of Cleaner Production, 2016b(112): 3977-3987.

[3] Alamgir M. A., M. M. Uddin, T. P. Tiwari, F. Marufa. Performance of wheat varieties under different tillage systems in Bangladesh, Conference on International Research on Food Security, Natural Resource Management and Rural Development organized by the Humboldt-Universität zu Berlin and the Leibniz Centre for Agricultural Landscape Research (ZALF), Tropentag 2015, Berlin, Germany, 2015 September 16-18

[4] Aziz I., T. Mahmood, K. R. Islam. Effect of long term no-till and conventional tillage practices on soil quality[J]. Soil and Tillage Research, 2013(131): 2835.

[5] Barma N.C.D., P. K. Malaker, Z. I. Sarker, M. A. Khaleque, M. Israil Hossain, M.A.Z. Sarker, M. Bodruzzaman, M.A Hakim, A. Hossain. Adoption of power tiller operated seeder in rice wheat cropping system[P]. WRC, BARI Annual report, Dinajpur, 2014: 248-253.

[6] Busari M. A., F. K. Salako. Effect of tillage, poultry manure and NPK fertilizer on soil chemical properties and maize yield on an Alfisol at Abeokuta, south-western Nigeria[J]. Nigerian Journal of Soil Science, 2013(23): 206-218.

[7] Cavigelli M. A., J. R. Teasdale, J. T. Spargo. Increasing crop rotation diversity improves agronomic, economic and environmental performance of organic grain cropping systems at the USDA-ARS Beltsville farming systems project. Plant Management Network.

https://dl.sciencesocieties.org/publications/cm/ pdfs/12/1/2013-0429-02-PS [Accessed at: 30 April, 2017].

[8] Derpsch R., T. Friedrich. Development and current status of no-till adoption in the World. Proceeding on CD. 18th Triennial Conference of the International Soil Tillage Research Organization (ISTRO), Izmir, 15-19 June, 2009.

[9] Giller K. E. Nitrogen fixation in tropical cropping systems. 2nd edition, Cabi Series, CABI Publishing series, 2001. Web: http://books.google.fr/books?id

[10] Gujarati N. D. Basic Econometrics, 3rd Edition. 
Singapore: McGraw-Hill Books company Inc. India. Implication for vulnerability analysis and mapping, World Food Programme, 1995.

[11] Fischer R.A., D. Byerlee, G. O. Edmeades. Can technology deliver on the yield challenge to 2050? In: Expert Meeting on How to Feed the World in 2050. FAO, Rome, 24-26 June, 2009.

[12] Haque M.E., R.W. Bell, Vance, W.H., Justice, S.E., Hossain, M.M., Mia, N.N. A new wave of conservation agriculture adoption on smallholder farms using planters for two wheel tractors: progress and bottlenecks for adoption in South Asia. Paper presented at 6th World Congress of Conservation Agriculture, Winnipeg, Canada, 2014.

[13] Haque M. E., R.W. Bell, R.K. Menon, M. M. Hossain. Comparative levels of soil disturbance under reduced and minimum tillage types with two-wheel tractor planting operations. 2nd Conference on Conservation Agriculture for Smallholders (CASH-II), Bangladesh Agricultural University, Mymensingh, Bangladesh, Eds. ME Haque, RW Bell, WH Vance, 2017: 62-63.

[14] Hossain M. I., M. S. Islam, C. A. Meisner, M. Bodruzzaman, I. Hossain. Minimum tillage one pass seeder for sustaining cropping intensity and profitability in rice-wheat system[J]. Int. J. Sustain. agril. Tech., 2009, 5(6): 32-37

[15] Hossain M. I., M. N. A. Siddiqui, G. M. Panaullah, J. M. Duxbury, J. G. Lauren. Raised beds: A resource conserving technology for improved crop production in Bangladesh. A booklet under Cornell University-Food for progress programme in Bangladesh, 2014.

[16] Hossain M. I., M. J. U. Sarker, M. A. Haque. Status of conservation agriculture based tillage technology for crop production in Bangladesh[J]. Bangladesh J. Agril. Res., 2015, 40(2): 235-248.

[17] IIRR \& ACT. Conservation Agriculture- A manual for farmers and extension workers in Africa. International Institute of Rural Re-construction (IIRR). Harare: Africa Conservation Tillage Network, 2005.

[18] Islam A.K.M., M.E. Haque, M.M. Hossain, M.A. Saleque, R.W. Bell. Water and fuel saving technologies: Un-puddled bed and strip tillage for wet season rice cultivation in Bangladesh. 19th World Congress of Soil Science, Soil Solutions for a Changing World, Brisbane, Australia, 2010.

[19] Islam A.K.M.S., M. M. Hossain, M. A. Saleque, M. A. Rabbani, R.I. Sarker. Energy consumption in un-puddled transplanting of wet season rice cultivation in north-west region of Bangladesh[J]. Prog. Agric., 2013(24): 229-237.
[20] Jacobsen S. E., C. R. Jensen, F. Liu. Improving crop production in the arid Mediterranean climate[J]. Field Crops Research, 2012(128): 34-47.

[21] Johansen C., M. E. Haque, R. W. Bell, C. Thierfelder, R. J. Esdaile. Conservation agriculture for small holder rain-fed farming: opportunities and constraints of new mechanized seeding systems[J]. Field Crops Research, 2012(132): 18-32.

[22] Keshavarzpour F., M. Rashidi. Effect of different tillage methods on soil physical properties and crop yield of watermelon (Citrullus vulgaris) [J]. World Applied Sciences Journal, 2008(3): 359-364.

[23] Khan S. A., R. L. Mulvaney, T. R. Ellsworth, C. W. Boast. The myth of nitrogen fertilization for soil sequestration[J]. Journal of Environmental Quality, 2007, 36(6): 1821-1832.

[24] Komarek A. Costs and benefits of crop residue retention in a Chinese subsistence farming system. Paper presented in the 57th AARES annual conference at the Sydney Convention and Exhibition Centre in Darling Harbour, Sydney, New South Wales, 5-8 February, 2013. Available at: http://ageconsearch.umn.edu/

[25] Lal R. Enhancing ecosystem services with no-till[J]. Renewable Agriculture and Food Systems, 2013(28): 102-114.

[26] Lauer J. The natural benefits of crop rotations and the cost of monocultures. University of Wisconsin-Madison, 2010. http://www.extesnion.umn.edu

[27] Miah M.A.M., S. Afroz, M. A. Rashid, S. A. M. Shiblee. Factors affecting adoption of improved sesame technologies in some selected areas in Bangladesh: An empirical study[J]. The Agriculturist, 2015, 13(1): 140-151.

[28] Murell T. S. The science behind the nitrogen credit for soybeans. International Plant Nutrient Institute (IPNI), 2011. http://www.ipni.net

[29] Reza M.S., M. M. H. Riazi, M. M. H. Khan. Productivity and profitability of sugarcane production in northern Bangladesh[J]. Indian Journal of Commerce \& Management Studies. 2016, 7(1): 38-45.

[30] Roy K. C., M. E. Haque, S. E. Justice, M. I. Hossain, C. A. Meisner. Development of agriculture tillage machinery for conservation agriculture in Bangladesh[J]. Agricultural Mechanization in Asia, Africa and Latin America, 2009(40): 58-64.

[31] Salahin N., M. K. Alam, A.T.M.A.I. Mondol, M.S. Islam, M. H. Rashid, M. A. Hoque. Effect of tillage and residue retention on soil Properties and crop yields in wheat-mungbean-rice crop rotation under 
subtropical humid climate[J]. Open Journal of Soil Science, 2017(7): 1-17.

[32] Sarker K.K., W. Xiaoyan, L. Hongwen, X. Chunlin, L. Wenying, H. Jin, E. R. Jeff, R.G. Rasaily, Q. Xiaodong. Development strategies of small scale conservation farming practices on two wheeled tractor in Bangladesh[J]. African Journal of Agricultural Research, 2012, 7(26): 3747-3756.

[33] Silva J. R.V., N. V. Costa, D. Martins. Efeito da palhada de cultivares de cana-de-açúcar na emergência de Cyperus rotundus[J]. Planta Daninha, 2003(21): 375-380.

[34] Singh Y., B. Singh, J. Timsina. Crop residue management for nutrient cycling and improving soil productivity in rice-based cropping practices in the tropics[J]. Advances in Agronomy, 2005(85): 269407.

[35] Singh N.P., R.P. Singh, R. Kumar, A.K. Vashist, F. Khan, N. Varghese. Adoption of resource conservation technologies in Indo-Gangetic plains of India: scouting for profitability and efficiency[J]. Agricultural Economics Research Review, 2011, 24(1): 1524.

[36] Singh O. P., H. P. Singh, P. S. Badal, R. Singh, D. Pandey. Impact of resource conservation technologies on carbon emission in major wheat growing regions of India[J]. Indian Journal of Agricultural
Economics, 2010, 65(3): 399-411.

[37] Teetes G., B. B. Pendelon. Insects-pests of sorghum: cultural management methods. Department of Entomology, Texas A\&M University, 1999.

http://www. sorghumipm.tamu.edu

[38] Tiwari K. N. Reassessing the role of fertilizers in maintaining food, nutrition and environmental security[J]. Indian Journal of Fertilizers, 2007(3): 33-50.

[39] Velini E. D., E. Negrisoli. Controle de Plantas Daninhas em cana crua. In: Conresso Brasileiro da Ciência das Plantas Daninhas. Foz do Iguaçu Anais. Foz do Iguaçu: Sociedade Brasileira da Ciência das Plantas Daninhas, 2000: 148-164.

[40] Yokouchi T., K. Saito. Factors affecting farmers' adoption of NERICA upland rice varieties: the case of a seed producing village in central Benin[J]. Food Sec., 2016(8): 197-209.

DOI: $10.1007 / \mathrm{s} 12571-015-0545-7$

[41] Hobbs P. R., K. Sayre, R. Gupta. The role of conservation agriculture in sustainable agriculture[J]. Philosophical Transactions of the Royal Society B: Biological Sciences, 2008 363(1491): 543-555.

[42] Kumar V., R. R. Bellinder, R. K. Gupta, R. K. Malik, D. C. Brainard. Role of herbicide-resistant rice in promoting resource conservation technologies in rice-wheat cropping systems of India: a review $[\mathrm{J}]$. Crop Protection, 2008(27): 290-301. 